\title{
Examination of Brevibacterium linens by an Electrophoretic Zymogram Technique
}

\author{
By H. F O I S S Y \\ Institut für Milchwirtschaft und Mikrobiologie, \\ Hochschule für Bodenkultur, A-ı I80 Wien, Austria
}

(Received 21 June 1973; revised 29 August 1973)

SU M M A R Y

Fifteen isolates of Brevibacterium linens were tested by polyacrylamide gel electrophoresis. Protein patterns and zymograms of 18 intracellular enzyme activities $(\alpha$-naphthyl acetate and $\beta$-naphthyl butyrate esterases, tributyrinase, alcohol-, lactate-, malate-, succinate-, glucose-6-phosphate-, 6-phosphogluconate-, isocitrate-, alanine- and glutamate-dehydrogenases, tetrazolium oxidase, catalase, peroxidase, arylamidase, proteinase and amylase) and four extracellular enzyme activities ( $\alpha$-naphthyl acetate esterase, arylamidase, proteinase and amylase) were examined. Enzyme activities were demonstrated by either specific staining reactions or by the subsequent diffusion of the proteins into a substrate layer. Striking variations of the enzyme patterns occurred among the strains. The variation, however, depended largely on the activity under consideration. Eight different enzymes were selected to calculate a matrix of similarity. The results indicated a separation of the strains into two major subdivisions or biotypes. Only one strain (BLI07) differed markedly from the others.

\section{INTRODUCTION}

The taxonomic status of Brevibacterium linens, technologically important for cheese ripening, has received comparatively little attention. When characterized by the morphological, physiological and biochemical criteria as listed in Bergey's Manual of Determinative Bacteriology (Breed, Murray \& Smith, I957) there are difficulties in differentiating Brevibacterium linens from several representatives of the genus Arthrobacter or Corynebacterium (Mulder et al. 1966; Da Silva \& Holt, 1965; Bousfield, 1972).

Since the usual biochemical routine tests do not discriminate between homologous and analogous metabolic pathways and frequently represent only a fraction of the genome, they fail to express the true genetic relationships between micro-organisms.

Grecz \& Dack (196I) tried to identify the pigmented strains of Brevibacterium linens by means of colour reactions. Friedman, Nelson \& Wood (I953) and Brandl \& Petutschnig (1972) described great differences in the proteolytic and lipolytic capacities of strains of B. linens.

The determination of the electrophoretic patterns of various enzyme activities (zymogram technique) which detect minor structural differences within the proteins has made a valuable contribution to microbial taxonomy (Garber \& Rippon, 1968; Baptist, Shaw \& Mandel, I969). Similar electrophoretic investigations have proved the usefulness of esterases (Morichi, Sharpe \& Reiter, 1968; El Sharkawy \& Huisingh, I97I), catalases (Cann \& Willox, I965; Robinson, I966) and various dehydrogenases (Bowman, Brubaker, Frischer \& Carson, I967; Baptist, Shaw \& Mandel, 1971). 
Table I. Strains of Brevibacterium linens studied and their sources

Strain*

BLI07

ATCC 9174

ATCC 9175

LAKTOFLORA208/BMSM/9

B

W

a

BW

$\mathrm{s}$

A

D

I

2

$\mathrm{CH} / \mathrm{O}$

$\mathrm{CH} / \mathrm{W}$
Source

Nederlands Institut voor Zuivelonderzoek (NIZO), Ede, The Netherlands Nederlands Institut voor Zuivelonderzoek (NIZO), Ede, The Netherlands Nederlands Institut voor Zuivelonderzoek (NIZO), Ede, The Netherlands

Dairy Research Laboratory, Association for the Production of Dairy Cultures, Prague, Czechoslovakia

Bundes-Lehr- und Versuchsanstalt für alpenländische Milchwirtschaft, Rotholz, Austria

Bundes-Lehr- und Versuchsanstalt für alpenländische Milchwirtschaft, Rotholz, Austria

Hochschule für Bodenkultur, Institut für Milchwirtschaft, Vienna, Austria,

Commercial culture, Grermany

Commercial culture, Austria

Isolated from an Austrian cheese

Isolated from an Austrian cheese

Isolated from a French cheese

Isolated from a French cheese

Isolated from a Swiss cheese

Isolated from a Swiss cheese

* Subsequently, strains BLI07, ATCC9I74, ATCC9I75 and LAKTOFLORA208/BMSM/9 are referred to as 107, 9I 74,9175 and 208 respectively.

Enzymatic investigations of $B$. linens established the presence of gelatinase, amylase, peroxidase, xanthine dehydrogenase, catalase and peptidase (Thomasow, 1950) and amino acid decarboxylase (Hosono \& Tokita, 1969a). Metabolic activities which give rise to volatile compounds from carbohydrates, fats and citric acid (Hosono, I968 $a$; Hosono \& Tokita, I $969 b$ ) and from amino acids (Hosono, 1968 $b$ ) have also been reported.

In the present work an electrophoretic zymogram technique was applied to several strains of Brevibacterium linens to ascertain their relationships.

\section{METHODS}

Bacteria and growth conditions. The strains (Table 1 ) had already been clearly characterized as Brevibacterium linens (E. Brandl \& K. Petutschnig, unpublished) by the usual tests of Breed et al. (I957). All were Gram-positive, produced catalase, liquefied gelatin, were lipolytic on tributyrin agar, reduced nitrate, turned litmus milk alkaline and grew in the presence of $15 \% \mathrm{NaCl}$. None of these strains produced acid from glucose, acetyl methyl carbinol, $\mathrm{H}_{2} \mathrm{~S}$ or indol. All produced an orange pigment except strains $\mathrm{CH} / \mathrm{W}$, A and ATCC9175.

Cultures maintained on nutrient agar (Difco) slants were used to inoculate $30 \mathrm{ml}$ of nutrient broth plus $0.1 \%$ casein according to Hammarsten (Merck, Darmstadt, Germany), incubated for $24 \mathrm{~h}$ at $20^{\circ} \mathrm{C}$ with vigorous rotary agitation. This culture was used to inoculate another $30 \mathrm{ml}$ volume and the incubation process was repeated. This was then used to inoculate $300 \mathrm{ml}$ of the same medium in I 1 Erlenmeyer flasks and incubated at $20{ }^{\circ} \mathrm{C}$ for $48 \mathrm{~h}$ with agitation.

Preparation of intracellular enzymes. The growth was harvested by centrifugation at $34000 \mathrm{~g}$ for $20 \mathrm{~min}$ at $4^{\circ} \mathrm{C}$, washed twice with physiological saline and finally suspended in distilled water at a concentration of approximately $\mathrm{I} \mathrm{g}$ wet $\mathrm{wt} / \mathrm{ml}$ and sonicated for $5 \mathrm{~min}$ at $\mathrm{I} \cdot 5 \mathrm{~A}$ in an ice bath. Cell debris was removed by centrifugation at $34000 \mathrm{~g}$ at $4{ }^{\circ} \mathrm{C}$ for 15 min. The supernatant was frozen immediately using dry ice and then lyophilized. Preparations were stored up to 2 weeks at $-20^{\circ} \mathrm{C}$. 
Preparation of extracellular enzymes. The supernatant from the first centrifugation was concentrated at $25^{\circ} \mathrm{C}$ in a rotary vaporizer I00: $\mathrm{I}$, dialysed overnight against tap water and stored at $-20^{\circ} \mathrm{C}$.

Disc-electrophoresis. Polyacrylamide gel electrophoresis was carried out according to the methods described by Maurer (197I). Electrophoresis was performed in the apparatus described by Foissy (I974a). Separation gels, containing I I $0 \%(\mathrm{w} / \mathrm{v})$ acrylamide were prepared with $0.3 \mathrm{M}$-tris to $0.06 \mathrm{M}$-hydrochloride buffer, $\mathrm{pH} 8.9$, in a glass tray of internal dimensions $240 \times 150 \times 3 \mathrm{~mm}$. The spacer gel consisted of $2.7 \%(\mathrm{w} / \mathrm{v})$ of acrylamide and a $0.05 \mathrm{M}$-tris to $0.06 \mathrm{M}$-hydrochloride buffer, $\mathrm{pH} 6.8$. The buffer in both the upper and the lower reservoirs was $5 \mathrm{~mm}$-tris to $0.04 \mathrm{M}$-glycine, $\mathrm{pH} \mathrm{8.3.} \mathrm{Sample} \mathrm{pockets} \mathrm{were} \mathrm{filled} \mathrm{with,}$ respectively, $30 \mu \mathrm{l}$ of a solution containing $2 \%$ intracellular proteins or $50 \mu \mathrm{l}$ of a concentrate prepared as described for extracellular preparations. In both cases sucrose was added to increase the density of the samples. Temperature was maintained at $4{ }^{\circ} \mathrm{C}$. The initial voltage, $150 \mathrm{~V}$, was increased to $35^{\circ} \mathrm{V}$ when the buffer front had reached the interface between the spacer and the separation gel. Electrophoresis was discontinued when the buffer front had run $10 \mathrm{~cm}$. To standardize results the relative electrophoretic mobilities of bands were calculated as $E_{f}$ values (ratio of the distance moved by the protein to the distance moved by the front) (Gottlieb \& Hepden, 1966). $\beta$-Casein A was used as the standard protein $\left(E_{f}=0.38\right)$.

\section{Localization of enzymes}

Esterases. After electrophoresis the gels were stained using the method of Lawrence, Melnick \& Weimer (1960).

Tributyrinase. The medium described by Lawrence, Fryer \& Reiter (1967) was used as a substrate. Gels were pressed on the substrate surface. Clearing of the tributyrin agar indicated tributyrinase activity.

Dehydrogenases. The methods of Green, Goldberg \& Blenden (1967) were used. After electrophoresis the gels were incubated in the dark at $37^{\circ} \mathrm{C}$ for approximately $2 \mathrm{~h}$ in a reaction mixture containing $15 \mathrm{mg}$ nicotinamide adenine dinucleotide (NAD), $50 \mathrm{mg}$ nitro blue tetrazolium chloride (NBT), $65 \mathrm{mg} \mathrm{KCN,} 2 \mathrm{mg}$ phenazine methosulphate (PMS) and $\mathrm{I} 00 \mathrm{ml}$ of $0 . \mathrm{I}$ M-tris-hydrochloride buffer, $\mathrm{pH} 8.5$. To this solution, $\mathrm{I} \cdot 8 \mathrm{~g}$ sodium-DLmalate, $2.7 \mathrm{~g}$ succinic acid disodium salt, $\mathrm{r} \cdot 69 \mathrm{~g}$ monosodium glutamate, $2 \mathrm{ml}$ sodium lactate $(60 \%$ syrup), or $0.9 \mathrm{~g}$ alanine were added, depending upon the enzymes being assayed.

Prior to polymerization $0.2 \% \mathrm{MgCl}_{2}$ was added to the gel solution as a cofactor for alcohol dehydrogenase. The reaction mixture consisted of $15 \mathrm{ml}$ substrate ( $1 \cdot 0 \mathrm{ml}$ absolute ethyl alcohol, $3.3 \mathrm{ml} \mathrm{I} \cdot 0 \mathrm{M}$-tris, in a total volume of $33 \mathrm{ml}$ distilled water), $9 \mathrm{mg} \mathrm{NAD}, 4 \mathrm{mg}$ PMS, $20 \mathrm{mg}$ NBT and $100 \mathrm{ml} 0 . \mathrm{I}$ M-tris-hydrochloride buffer, $\mathrm{pH} 8 \cdot 5$.

The methods of Baptist et al. (I97I) were used to detect glutamate, isocitrate, 6-phosphogluconate and glucose-6-phosphate dehydrogenases; nicotine amide adenine dinucleotide phosphate (NADP) was used instead of NAD as a cosubstrate. The substrates ( $1 \cdot 0 \mathrm{M}-$ sodium glutamate, 0.I M-trisodium isocitrate, 0.5 M-trisodium-6-phosphogluconate and $0.25 \mathrm{M}$-disodium glucose-6-phosphate, respectively) were dissolved in $0.5 \mathrm{M}$-tris-hydrochloride buffer, $\mathrm{pH} 7 \cdot \mathrm{x}$.

Tetrazolium oxidase. Patterns were tested as for the dehydrogenases, but with substrate omitted. Blank bands on the blue background marked areas of activity.

Catalase. The method was based on that of Robinson (1966). Prior to polymerization I $\%$ starch was added to the acrylamide gel solution. After electrophoresis the gel was immersed in $2 \%(\mathrm{v} / \mathrm{v})$ hydrogen peroxide solution, washed thoroughly with running water 
and then covered with acidic potassium iodine, $2 \%(\mathrm{w} / \mathrm{v})$, for 30 to $60 \mathrm{~s}$. Catalases appeared as white bands against the blue background.

Peroxidase. The method of Schrauwen (1966) was followed using a benzidine-guaiacolhydrogen peroxide system.

Proteinase. Activity was demonstrated after diffusion of the enzymes from the electropherograms into a gelatin agar layer. Areas of hydrolysis were developed with acidic mercuric chloride (Foissy, I974b).

Arylamidase. Following the method of Smith \& Rutenburg (I966) the gels were incubated for $5 \mathrm{~h}$ in a solution of L-leucyl- $\beta$-naphthyl-amide hydrochloride $(0.68 \mathrm{~mm})$ in $0 . \mathrm{I} \mathrm{M}$-phosphate buffer, $\mathrm{pH} 7{ }^{\circ}$. The diazonium salt Garnet $\mathrm{GBC}$ was used as a coupling agent for the naphthol released.

Amylase. It was necessary to add $3.0 \%(\mathrm{w} / \mathrm{v})$ starch to the polyacrylamide gel solution prior to polymerization. After electrophoresis the gels were incubated in a moist atmosphere for $24 \mathrm{~h}$. The unhydrolysed starch was stained with $2 \%(\mathrm{w} / \mathrm{v})$ acidic potassium iodine solution. White bands against a blue background showed amylase activity.

\section{RESULTS}

Preliminary tests showed that under the conditions chosen all of the enzymes studied were negatively charged. Thus only the anodic gels were examined.

The bacterial extracts were tested on numerous occasions to verify the existence of minor electrophoretic differences. Only bands which were consistently present were noted.

A complex protein pattern was detected in the electropherograms after staining with Coomassie-blue. This made comparison of the various strains difficult.

\section{Intracellular enzymes}

Fig. I, 2 and $3(a, b, c)$ are schematic drawings of the patterns of a few intracellular enzyme activities for 15 strains of Brevibacterium linens. The strains are listed according to the similarities of their esterase patterns and this system is maintained for all diagrams.

Esterolytic activity against synthetic substrates was found in all strains of Brevibacterium linens examined (Fig. I $a, b$ ). $\beta$-Naphthyl butyrate as a substrate showed more esterolytic enzymes than $\alpha$-naphthyl acetate, as seen in the increased number of faint bands. Except for strain 107 , all strains showed strongly stained bands at $E_{f}=0.58$ or $E_{f}=0.65$. These main esterase bands also reacted with tributyrin.

The dehydrogenases were also multimolecular systems. Seven of the 15 strains (BW, W, $9 \mathrm{I} 74,2, \mathrm{CH} / \mathrm{W}, \mathrm{CH} / \mathrm{O}$, a) possessed a strong band at $E_{f}=0.35$ which was evident when malate, succinate, glucose-6-phosphate or 6-phosphogluconate were used as a substrate. The highest activity occurred in the case of 6-phosphogluconate. Strain 107 was again different as it possessed a double band at $E_{f}=0.4 \mathrm{I}$ to 0.43 . Despite their heterogeneous general impression, the complex dehydrogenase patterns did reveal analogies between certain strains. However, they were not as good as those based on esterase patterns.

A single band of catalase activity occurred in a small $E_{f}$-range with only minor variations, except for strain I which possessed two bands.

The tetrazolium oxidase patterns were very similar, band $E_{f}=0.45$ occurred in I I of the strains.

Arylamidase and amylase activities were not detectable in the intracellular preparations. 


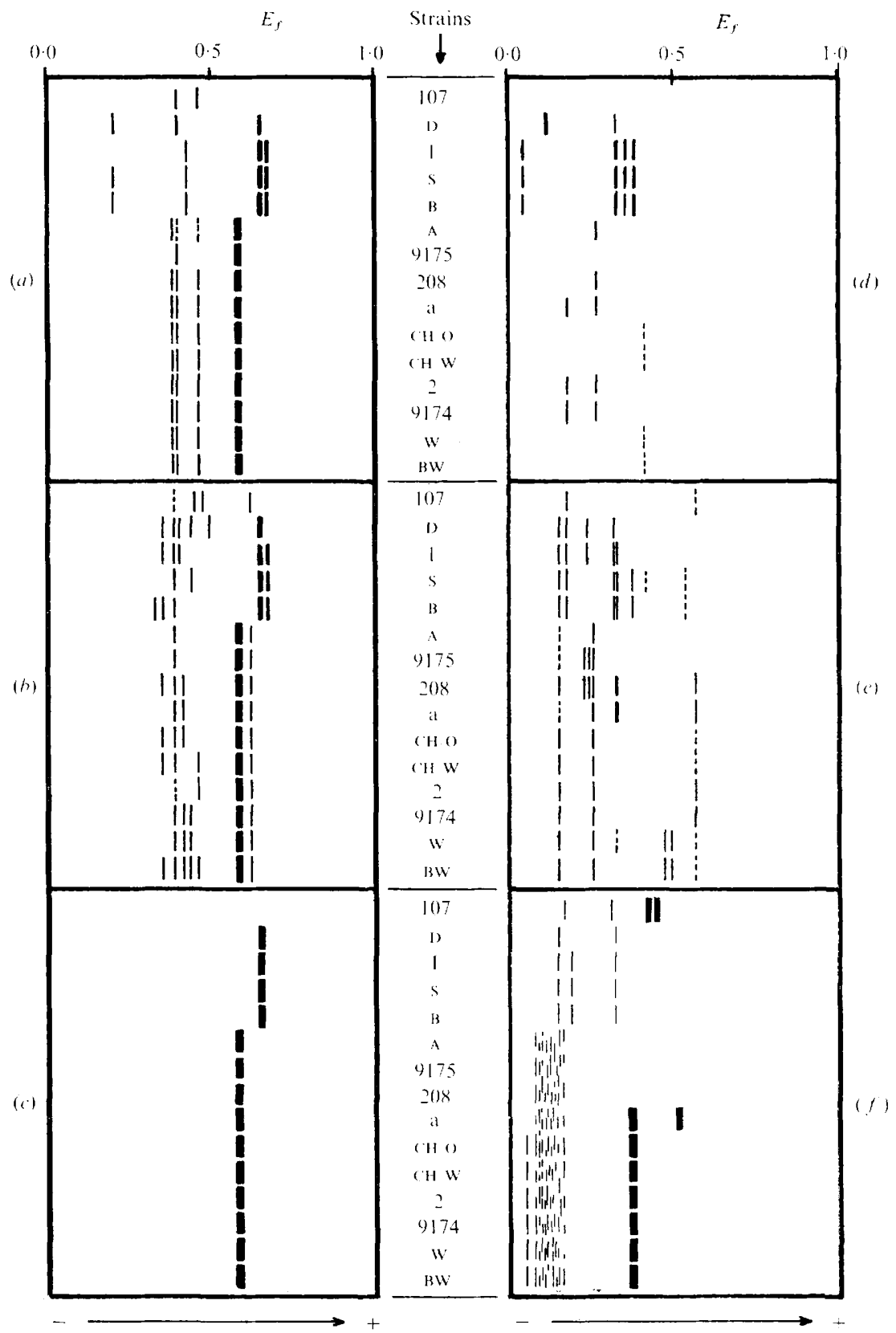

Fig. I. Electrophoretic patterns of enzyme activities of some Brevibacterium linens strains. Intracellular activities: ( $a$ ) $\alpha$-naphthyl acetate esterase; $(b) \beta$-naphthyl butyrate esterase; $(c)$ tributyrinase; $(d)$ alcohol dehydrogenase; $(e)$ lactate dehydrogenase; $(f)$ malate dehydrogenase. 


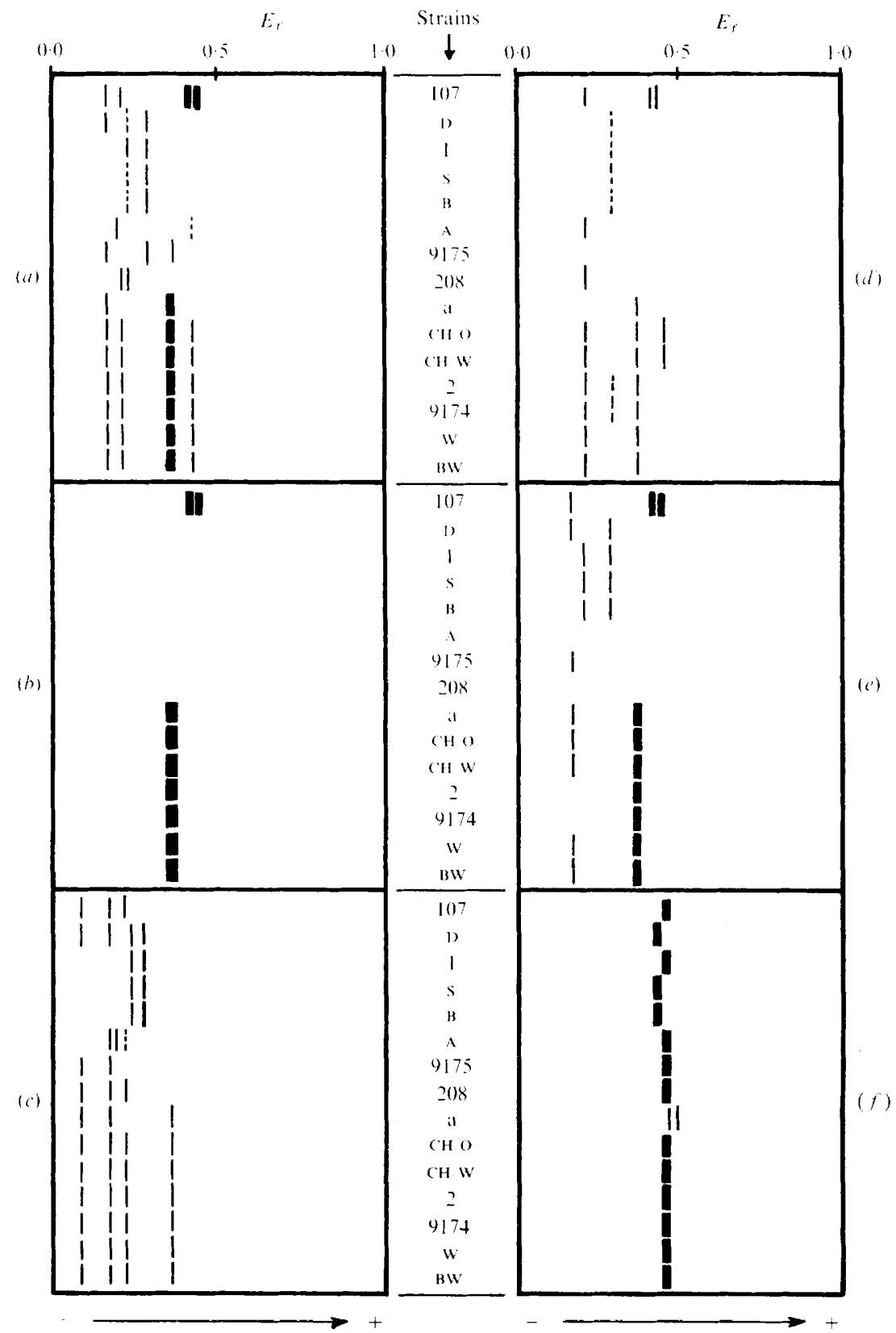

Fig. 2. Electrophoretic patterns of enzyme activities of some Brevibacterium linens strains. Intracellular activities: (a) succinate dehydrogenase; (b) glucose-6-phosphate- and 6-phosphogluconate dehydrogenases; $(c)$ isocitrate dehydrogenase; $(d)$ alanine dehydrogenase; $(e)$ glutamate dehydrogenase; $(f)$ tetrazolium oxidase. 


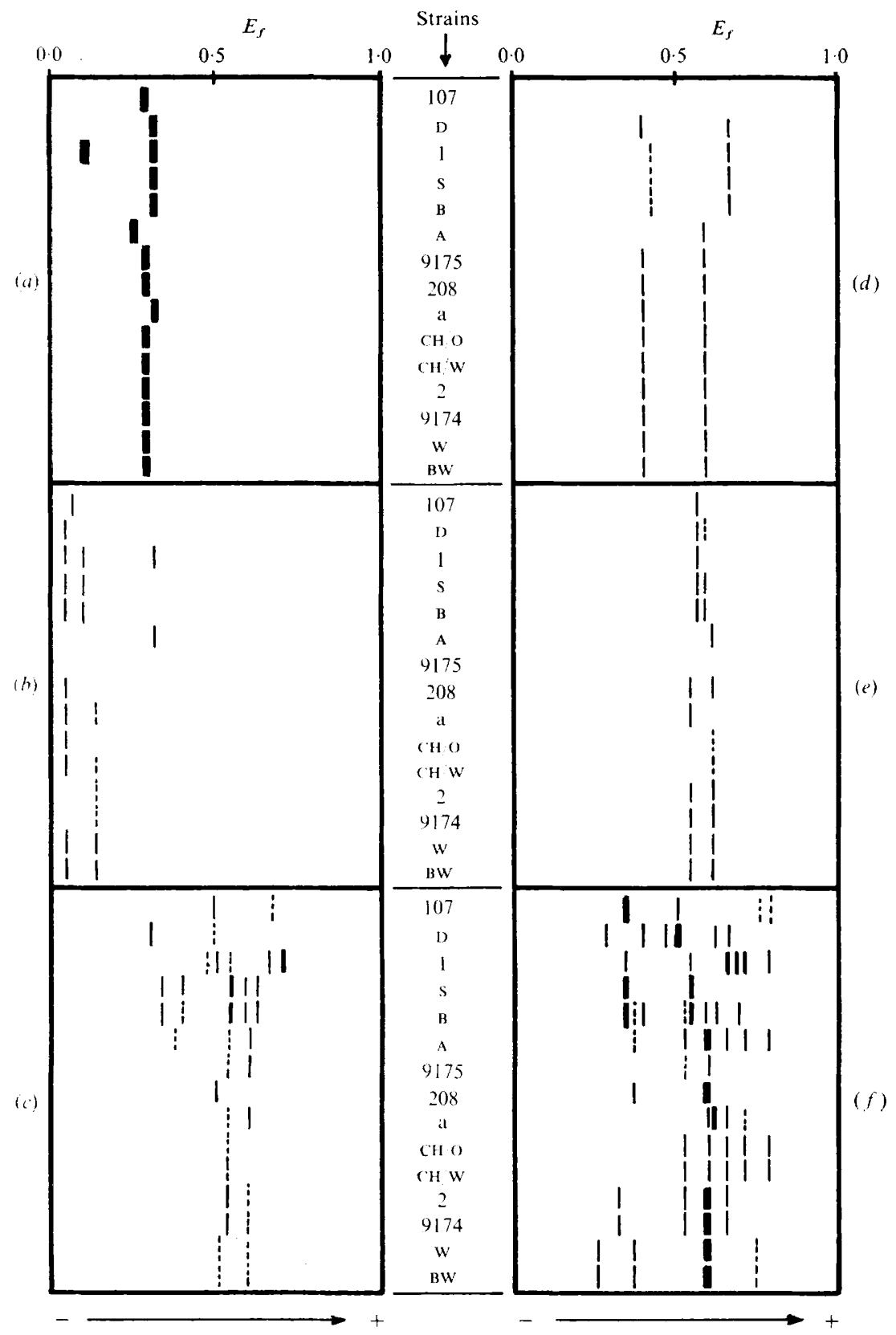

Fig. 3. Electrophoretic patterns of enzyme activities of some Brevibacterium linens strains. Intracellular activities: $(a)$ catalase; $(b)$ peroxidase; $(c)$ proteinase. Extracellular activities: $(d) \alpha$-naphthyl acetate esterase; $(e)$ arylamidase; $(f)$ proteinase. 


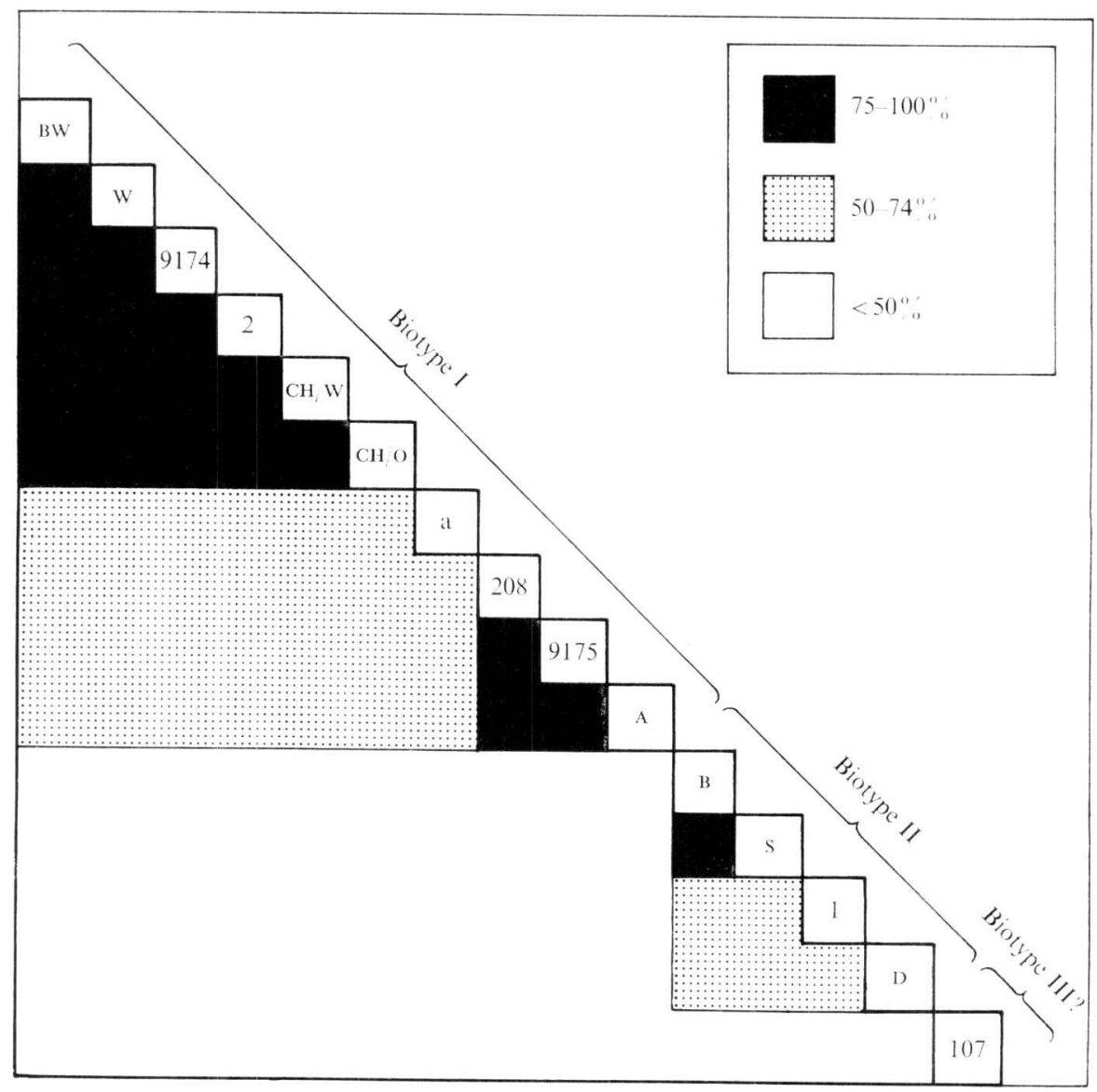

Fig. 4. Matrix of similarity coefficients of eight enzymes of Brevibacterium linens strains. Data are from Fig. I $(b, d, e, f)$, Fig. $2(a, c, f)$ and Fig. $3(a)$.

\section{Extracellular enzymes}

Fig. $3(d, e, f)$ summarizes the enzyme activity in the extracellular preparations examined. Distinct and highly reproducible patterns could be detected among the proteinases. The esterase pattern was weak and showed correlations with intracellular main bands. Arylamidase activity was also weak. No amylase activity was detectable.

\section{Determination of similarity}

The results of the intracellular activities of $\beta$-naphthyl butyrate esterases, alcohol-, lactate-, malate-, succinate- and isocitrate-dehydrogenases, and tetrazolium oxidases and catalases were used as a representative sample to calculate the matrix of similarity shown in Fig. 4 . The similarity of each pair of strains was calculated as the percentage of enzymes which appeared to be the same type, out of the total number of enzymes available for comparison with that pair. 


\section{DISCUSSIO N}

We wished to see if the electrophoretic differentiation of the enzyme contents of 15 strains of Brevibacterium linens could be used as an improved basis for an objective differentiation, because by the usual bacteriological tests all strains appeared identical except that strains ATCC9I75, A and $\mathrm{CH} / \mathrm{W}$ lacked pigmentation.

In view of the large number of proteins resolved by Coomassie-blue staining the determination of enzyme patterns appeared to be a useful criterion for differentiation within the species Brevibacterium linens, although it may not always be true that enzymes giving the same banding pattern are identical.

The results indicated a division into two major subgroups based on esterase patterns (strains $\mathrm{BW}, \mathrm{w}, 9174,2, \mathrm{CH} / \mathrm{W}, \mathrm{CH} / \mathrm{O}, \mathrm{a}, 208,9175$ and A labelled biotype I, and strains $\mathrm{B}, \mathrm{S}, \mathrm{I}$ and D labelled biotype II, see Fig. 4). Strain 107 is unique because it lacked one of the two esterases present in all the other strains.

On the basis of the presence or absence of the typical dehydrogenase band at $E_{f}=\mathrm{c} \cdot 35$, it was also possible to divide all the strains (except for strain 107) into two groups. This division differed from that based on esterases. Strains 208, 9175 and A, which were in the same esterase group as strains $\mathrm{BW}, \mathrm{W}, 9 \mathrm{I} 74,2, \mathrm{CH} / \mathrm{W}, \mathrm{CH} / \mathrm{O}$ and a, appeared in the same group as strains B, S, I and D because they did not exhibit the main dehydrogenase band at $E_{f}=0.35$. However, when a larger number of electrophoretic features were used to compare similarity, strains 208,9175 and A exhibited a greater resemblance to the group in which they fell on the basis of esterase patterns (Fig. 4).

Additionally, although strain a showed the characteristic dehydrogenase activity at $E_{f}=0.35$, it did not reach the level of $75 \%$ similarity with the other strains in the esterase subgroup because of its succinate dehydrogenase, tetrazolium oxidase and catalase patterns.

The results of the matrix of similarity based on enzyme activities indicates that the Brevibacterium linens strains examined fall into recognizably different groups. The division, however, depends on the percentage level of similarity chosen as a basis, but this is always so (see Sneath, 1972). Assuming that a similarity of more than $50 \%$ calculated from zymograms suffices for a classification into biotypes, we would include within biotype I strains $\mathrm{BW}, \mathrm{W}, 9174,2, \mathrm{CH} / \mathrm{W}, \mathrm{CH} / \mathrm{O}, \mathrm{a}, 208,9175$ and $\mathrm{A}$, and in biotype II strains $\mathrm{B}, \mathrm{S}$, I and D (Fig. 4). The results with strain 107 indicate that it belongs to a different subgroup. The establishment of a third biotype would be justified if this particular type could be detected again when testing a greater number of strains. This division corresponds exactly with that according to esterase profiles alone and it is interesting that Norris (I964) demonstrated good correlations between esterase patterns and serological relationships in the genus Bacillus.

The extent to which the two biotypes characterized in this study can be differentiated by improved or different physiological and biochemical tests should be investigated. Absence of pigmentation in Brevibacterium linens is apparently not so decisive a factor as to justify another species. This is in line with the results of Crombach (I97I), who could detect no striking differences in the GC-ratio in a DNA analysis of pigmented and non-pigmented strains.

The extracellular esterase, arylamidase and proteinase patterns appear to be of little taxonomic value but are of interest in cheese ripening. Differences in these features might be the reason for the different proteolytic capacities of various strains, but the production of these enzymes depends greatly on physiological and biochemical conditions.

Mention should be made of the proteinase patterns, which show a high degree of heterogeneity. However, in the case of biotype I especially it seems that the individual profiles are 
based primarily on the ability of each strain to produce one or other enzyme isoactivity from a probable group-specific pattern of proteinases or, to be more specific, gelatinases. Relations between individual extracellular proteinase patterns and their technological applicability are at present being studied.

I thank E. Brandl for his continuous support and encouragement during this research, and G. Kreil (Vienna) and B. Reiter, M. E. Sharpe and E. I. Garvie (Shinfield, Reading) for advice and criticism. The help of F. Schnabl in growing bacterial cultures and the expert technical assistance of W. Fleschurz is gratefully acknowledged. This study was supported by a research grant in I 968 from the Österreichische Nationalbank.

\section{REFERENCES}

BAPtist, J. N., SHAw, C. R. \& MANDEL, M. (1969). Zone electrophoresis of enzymes in bacterial taxonomy. Journal of Bacteriology $99, \mathrm{I} 80-\mathrm{I} 88$.

Baptist, J. N., Shaw, C. R. \& Mandel, M. (I97I). Comparative zone electrophoresis of enzymes of Pseudomonas solanacearum and Pseudomonas cepacia. Journal of Bacteriology 108, 799-803.

Bousfield, I. J. (1972). A taxonomic study of some coryneform bacteria. Journal of General Microbiology 7I, $44 \mathrm{I}-455$.

Bowman, J. E., Brubaker, R. R., Frischer, H. \& Carson, P. E. (1967). Characterization of Enterobacteria by starch gel electrophoresis of glucose-6-phosphate dehydrogenase and phosphogluconate dehydrogenase. Journal of Bacteriology 94, 544-55I.

Brande, E. \& Petutschnig, K. (1972). Orientierende Untersuchungen über die proteolytische und lipolytische Aktivität einiger Brevibacterium linens-Stämme verschiedener Herkunft. Österreichische Milchwirtschaft (Wissenschaftliche Beilage) 27, 17-25.

Breed, R. S., Murray, E. G. D. \& Smith, N. R. (1957). Bergey's Manual of Determinative Bacteriology, 7 th edn. Baltimore: Williams and Wilkins.

CanN, D. C. \& Willox, M. E. (1965). Analysis of multimolecular enzymes as an aid to the identification of certain rapidly growing mycobacteria, using starch gel electrophoresis. Journal of Applied Bacteriology 28, $165-173$.

СRомвасH, W. H. J. (197I). DNA base composition and DNA homology of coryneform bacteria, isolated from soil, cheese and sea fish. Journal of General Microbiology 69, xii.

DA Silva, N. G. A. \& Holt, J. G. (1965). Numerical taxonomy of certain coryneform bacteria. Journal of Bacteriology 90, $921-927$.

El-Sharkawy, T. A. \& Huisingh, D. (1971). Electrophoretic analysis of esterases and other soluble proteins from representatives of phytopathogenic bacterial genera. Journal of General Microbiology 68, I49-154.

Forssy, H. (1974a). An instruction for a home-made slab gel electrophoresis cell of glass. Laboratory Practice (in the Press).

Forssy, H. (1974b). A method for the detection of proteolytic isoactivities after polyacrylamide gel electrophoresis. Journal of Applied Bacteriology (in the Press).

Friedman, M. E., Nelson, W. O. \& Wood, W. A. (1953). Proteolytic enzymes from Bacterium linens. Journal of Dairy Science 36, I I24-1 I34.

Garber, E. D. \& Rippon, J. W. (1968). Proteins and enzymes as taxonomic tools. Advances in Applied Microbiology 10, I37-I39.

Gottlieb, D. \& HePden, P. M. (I966). The electrophoretic movement of proteins from various Streptomyces species as a taxonomic criterion. Journal of General Microbiology 44, 95-104.

Grecz, N. \& DACK, G. M. (196I). Taxonomically significant color reactions of Brevibacterium linens. Journal of Bacteriology 82, 24I-246.

Green, S. S., GoldberG, H. S. \& Blenden, D. C. (1967). Enzyme patterns in the study of Leptospira. Applied Microbiology 15, I104-I113.

Hosono, A. (1968a). Production of volatile fatty acids by Brevibacterium linens. I. Formation of volatile fatty acids from individual amino acids. Japanese Journal of Zootechnical Science 39, 156-16 I .

Hosono, A. (1968b). Production of volatile fatty acids by Brevibacterium linens. II. Formation of volatile fatty acids from some carbohydrates and butter fat. Japanese Journal of Zootechnical Science 39, 2 I2219. 
Hosono, A. \& Tokita, F. (1969a). Studies on the decarboxylation of amino acids by Brevibacterium linens. Japanese Journal of Zootechnical Science 40, 544-550.

Hosono, A. \& Tokita, F. (I969 $b$ ). Studies on the production of volatile carbonyl compounds by Brevibacterium linens. Japanese Journal of Zootechnical Science 40, 277-283.

Lawrence, R. C., Fryer, T. F. \& Reiter, B. (1967). Rapid method for the quantitative estimation of microbial lipases. Nature, London 213, 1264-I 265.

Lawrence, S. H., Melnick, P. J. \& Weimer, H. E. (I960). A comparison of serum proteins and enzymes by starch gel electrophoresis. Proceedings of the Society for Experimental Biology and Medicine 105, 572-575.

Maurer, H. R. (1971). Disc Electrophoresis and Related Techniques of Polyacrylamide Gel Electrophoresis, 2nd edn. Berlin and New York: Walter de Gruyter.

Morichi, T., Sharpe, M. E. \& Reiter, B. (1968). Esterases and other soluble proteins of some lactic acid bacteria. Journal of General Microbiology 53, 405-414.

Mulder, E. G., Adamse, A. D., Antheunisse, J., Deinema, M. H., Woldendorp, J. W. \& Zevenhuizen, L. P. T. M. (I966). The relationship between Brevibacterium linens and bacteria of the genus Arthrobacter. Journal of Applied Bacteriology 29, 44-7I.

NoRrIS, J. R. (I964). The classification of Bacillus thuringiensis. Journal of Applied Bacteriology 27, 439-447.

RoBinson, K. (1966). An examination of Corynebacterium spp. by gel electrophoresis. Journal of Applied Bacteriology 29, I79-184.

Schrauwen, J. A. M. (1966). Nachweis von Enzymen nach elektrophoretischer Trennung an PolyacrylamidSäulchen. Journal of Chromatography 23, I77-180.

Smith, E. D. \& Rutenburg, A. M. (1966). Starch gel electrophoresis of human tissue enzymes which hydrolyze L-leucyl- $\beta$-naphthylamide. Science, New York 152, I256-1 257.

SNeath, P. H. A. (1972). Computer taxonomy. In Methods in Microbiology, vol. i A, pp. 29-98. Edited by J. R. Norris and D. W. Ribbons. London: Academic Press.

Tномаsоw, J. (1950). Über die Enzyme des Brevibacterium linens. Kieler Milchwirtschaftliche Forschungsberichte 2, 35-62. 